\title{
Soaking curve and effect of temperature on the germination of daisy seeds
}

\author{
Rogério G Pêgo; José Antônio S Grossi; José Geraldo Barbosa \\ UFV, Depto. Fitotecnia, 36571-000 Viçosa-MG; engagropego@yahoo.com.br; jgrossi@ufv.br; jgeraldo@ufv.br
}

\begin{abstract}
The soaking curve and the effect of temperature on the germination of daisy seeds (Chrysanthemum leucanthemum) were characterized in this study. To determine the soaking curve, four samples of $0.5 \mathrm{~g}$ of seeds were soaked in germitest paper moistened with distilled water and maintained in germinator at $25^{\circ} \mathrm{C}$. The seeds were weighed in periods of $0,3,6,9,12,24,36,48,60,72,84$ and 96 hours using a precision digital balance of $0.0001 \mathrm{~g}$. A triphasic pattern germination curve was adjusted, allowing the determination of the beginning and duration of the phase II of the germination process. The germination test was carried out with four replications of 50 seeds disposed in "Gerbox" boxes and placed in germinators at the temperatures of $20,25,30$ or $20-30^{\circ} \mathrm{C}$. A completely randomized experimental design was used with four replications of 50 seeds. The data were submitted to the analysis of variance and the averages were compared by the Tukey test, at $5 \%$ of probability. For analysis of accumulated seed germination, regressions were adjusted based on period of experiment. The seeds presented a triphasic pattern of germination and the phases I and II lasted 12 and 48 hours, respectively. The best temperature for the germination of the seeds is $25^{\circ} \mathrm{C}$. The temperature of $30^{\circ} \mathrm{C}$ promoted the thermoinhibition of germination and increased the dead and dormant seeds and abnormal seedlings.
\end{abstract}

Keywords: Chrysanthemum leucanthemum, thermoinhibition, floriculture, ornamental.

\begin{abstract}
RESUMO
Curva de embebição e efeito da temperatura na germinação de sementes de margarida

A curva de embebição e o efeito da temperatura sobre a germinação de sementes de margarida (Chrysanthemum leucanthemum) foram caracterizados. Para determinar a curva de embebição, quatro amostras de $0,5 \mathrm{~g}$ de sementes foram embebidas em papel germitest umedecido com água destilada e mantidas em germinador a $25^{\circ} \mathrm{C}$. As sementes foram pesadas em períodos de 0 , $3,6,9,12,24,36,48,60,72,84$ e 96 horas, com auxílio de balança de precisão digital de 0,0001 g. Foi ajustada uma curva trifásica padrão de germinação, permitindo a determinação do início e a duração da fase II do processo de germinação. O teste de germinação foi realizado com quatro repetições de 50 sementes dispostas em caixas "gerbox" mantidas em germinadores nas temperaturas de 20 , 25,30 ou $20-30^{\circ} \mathrm{C}$. O delineamento experimental foi inteiramente casualizado. Os dados foram submetidos à análise de variância e as médias comparadas pelo teste de Tukey a $5 \%$ de probabilidade. Para análise da germinação acumulada das sementes foi feita regressão em função dos dias de avaliação. A embebição de sementes de margarida apresentou padrão trifásico de germinação e as fases I e II duraram 12 e 48 horas, respectivamente. A melhor temperatura para a germinação das sementes de margarida foi $25^{\circ} \mathrm{C}$. A temperatura de $30^{\circ} \mathrm{C}$ promoveu termoinibição de germinação e aumentou a porcentagem de sementes mortas e dormentes e plântulas anormais.
\end{abstract}

Palavras-chave: Chrysanthemum leucanthemum, termoinibição, floricultura, ornamental.

(Recebido para publicação em 9 de junho de 2011; aceito em 31 de maio de 2012) (Received on June 9, 2011; accepted on May 31, 2012)

$\mathrm{T}$ he Brazilian market of flowers and ornamental plants is increasing and it is estimated that Brazilian floriculture currently moves about 750 million dollars per year (Landgraf \& Paiva, 2009). In this market, it is possible to commercialize cut flowers or potted plants for flower arrangements, interior design or landscape projects (Ceratti et al., 2007). Daisy (Chrysanthemum leucanthemum) is a species that can be produced to meet any of the demands of this market due to its versatile use. The Companhia de Entrepostos e Armazéns Gerais de São Paulo (CEAGESP) reported that the average price of daisy stems in April 2010 was $\mathrm{R} \$ 8.70$ per bunch of $1.0 \mathrm{~kg}$, which demonstrates the commercial relevance of this species (CEAGESP, 2010).

The successful production of ornamental plants is determined by the adequate implantation of the culture; for such, it is fundamental to use seedlings of height phytosanitary quality. The propagation of daisy may occur asexually or sexually. The asexual propagation is an unusual practice due to the reduced number of seedlings achieved from the mother plant. Thus, sexual propagation is more commonly used (Mitich, 2000). The field conditions usually present difficulties related to temperature, water, light and other biotic and abiotic factors that affect the germination of seeds of agricultural cultures, leading to the late emergence or failures on stand, reducing the uniformity of stand and the production in the harvest (Stefanello et al., 2006; Kikuti \& Marcos Filho, 2007). Thus, the knowledge about the processes that occur during the soaking of seeds and the factors that affect germination are fundamental for daisy production.

Seed germination is strongly affected by the conditions of temperature and humidity of the environment. In optimum conditions, it is possible to 
observe a triphasic pattern curve of soaking process (Bewley \& Black, 1994). The determination of soaking curve and the definition of change phases during germination allow adjustments of methodologies for seed osmoconditioning, which are frequently used to homogenize the germination and emergence of seedlings in the field (Rodrigues et al., 2009). Besides, the determination of soaking phases allows to achieve adjustments in several tests of seed vigor used in the analysis of the physiological quality of seeds, such as water stress, and the tetrazolium test, to discriminate the vigor of seed lots and destine them to be traded (Marcos Filho, 1999; Rodrigues et al., 2008).

Temperature may influence the percentage of germination, affecting both the speed of water absorption and the biochemical reactions (Amato et al., 2007). Temperatures within optimum ranges promote the development of normal seedlings, but low temperatures lead to lower seedlings production, and the higher temperatures cause enzymatic disorders (Marcos Filho, 1999). High temperatures cause changes in the levels of phytohormones associated to the germination of seeds, mainly abscisic acid and gibberellin, by a process called thermoinhibition of germination (Akman, 2009). Thermoinhibition is mentioned as responsible for the high percentages of dormant seeds or formation of abnormal seedlings due to lower cell elongation (Toh et al., 2008).

The Rules for Seed Analysis (RAS) present specific methodologies of temperature and dormancy breaking for germination tests of several species of the genus Chrysanthemum, but there are no established conditions for the species C. leucanthemum (Brasil, 2009). Thus, the objective of this study was to characterize the soaking curve and to define the effect of temperature on the germination of daisy seeds.

\section{MATERIAL AND METHODS}

The present work was carried out in a laboratory of the Federal University of Viçosa (Minas Gerais state, Brazil). Seeds of the cultivar Gigante Branca were evaluated.
Initially, seed moisture content was determined by the official method of drying in kiln at $105 \pm 3^{\circ} \mathrm{C}$ for 24 hours, according to the Rules for Seed Analysis (Brasil, 2009). To determine the soaking curve, four replications of $0.5 \mathrm{~g}$ of seeds were placed in "Gerbox" boxes over two sheets of germitest paper moistened with distilled water at the proportion of 2.5 times their weight and maintained in germinator at $25^{\circ} \mathrm{C}$. In the periods of $0,3,6,9,12,24,36,48,60,72,84$ and 96 hours, the seeds were removed from the "Gerbox" boxes and carefully dried with towel paper for the removal of the excess of water adhered to the surface of the tegument and immediately weighed in a digital balance, with the precision of $0.0001 \mathrm{~g}$. The weight gain of the seeds was calculated by the formula:

$$
\mathrm{GP}=[(\mathrm{Pf}-\mathrm{Pi}) / \mathrm{Pi}] \times 100
$$

Where $\mathrm{GP}=$ weight gain $(\%) ; \mathrm{Pf}=$ final weight (weight in grams at each soaking period); $\mathrm{Pi}=$ initial weight of the seeds in grams, before soaking.

The germination test was carried out with four replications of 50 seeds disposed in "Gerbox" boxes on two germitest paper sheets moistened with distilled water at the proportion of 2.5 times their weight and maintained in a germinator at the temperature of $20,25,30$ or $20-30^{\circ} \mathrm{C}$. All seeds were germinated at 8 hours photoperiod under white light of fluorescent lamp, submitted to alternating temperatures, the highest temperature $\left(30^{\circ} \mathrm{C}\right)$ was released during light period and the lowest $\left(20^{\circ} \mathrm{C}\right)$, during the night period. The number of normal seedlings was counted in the first germination counting (FGC) carried out seven days after the beginning of the test. The second germination counting (SGC) was carried out 16 days after the beginning of the test, and the number of germinated seedlings was evaluated, accordingly to the Rules for Seed Analysis (Brasil, 2009). In the second germination counting, the number of normal and abnormal seedlings, dormant seeds (non-germinated) and dead seeds were also counted.

To determine the germination speed index (GSI), the number of germinated seeds was counted daily. The seeds with primary root protrusion with $1.0 \mathrm{~mm}$ of length were considered germinated to calculate the GSI. The GSI was calculated according to Maguire (1962), by the expression:

$$
\mathrm{GSI}=(\mathrm{G} 1 / \mathrm{N} 1)+(\mathrm{G} 2 / \mathrm{N} 2)+\ldots+
$$
(Gn / Nn)

Where $\mathrm{G} 1=$ number of germinated seeds in the first counting; N1= number of days elapsed before the first counting; $\mathrm{G} 2=$ number of germinated seeds in the second counting; N2= number of days elapsed before the second counting; $n=$ last counting.

We established a curve that adjusted to a triphasic pattern of the germination that allowed the determination of the beginning and duration of the phase II of the germination process. A completely randomized experimental design was used for the germination test, with four replications and 50 seeds per replication. The data were submitted to the analysis of variance and the effects of the treatments were compared by the Tukey test, at $5 \%$ of probability, with the use of the SISVAR statistical analysis software system, version 4.0. To obtain the soaking curve and the accumulated germination of seeds, polynomial models of third degree and sigmoid were fitted in function of evaluation periods, respectively.

\section{RESULTS AND DISCUSSIONS}

The degree of moisture content of the seeds during the performance of the experiments was $7.8 \%$.

The soaking process starts with the contact of the seeds with the moistened substrate (Figure 1), leading to the inference that the seeds do not present restrictions to water absorption, and the increased size of the seeds is visible in the first 12 hours. A triphasic pattern is observed in the soaking of the seeds, similarly to that found in black sucupira (Bowdichia virgilioides) (Albuquerque et al., 2009).

The phase I was characterized by a high gain of the moisture content in the first 12 hours of soaking, of about 100\% (Figure 1). This phase is characterized by the high absorption of water, necessary to the germination process (Guimarães et al., 2008). Similar results 


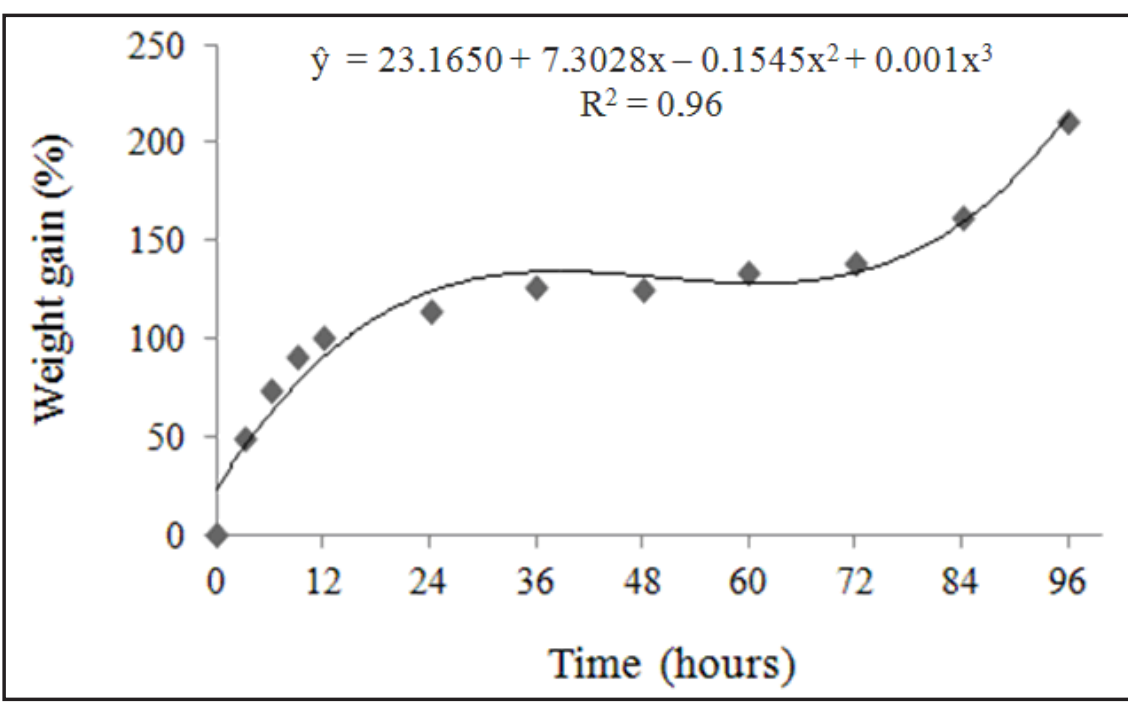

Figure 1. Soaking curve of daisy seeds at $25^{\circ} \mathrm{C}$ (curva de embebição de sementes de margarida a $\left.25^{\circ} \mathrm{C}\right)$. Viçosa, UFV, 2009.

Table 1. First germination counting (FGC), second germination counting (SGC) and germination speed index (GSI) of daisy seeds submitted to different temperatures (primeira contagem de germinação (FGC), segunda contagem de germinação (SGC) e índice de velocidade de germinação (GSI) de sementes de margarida submetidas a diferentes temperaturas). Viçosa, UFV, 2009.

\begin{tabular}{lccc}
\hline $\begin{array}{l}\text { Temperature } \\
\left({ }^{\circ} \mathbf{C}\right)\end{array}$ & $\begin{array}{c}\text { Second germination } \\
\text { counting (\%) }\end{array}$ & $\begin{array}{c}\text { First germination } \\
\text { counting (\%) }\end{array}$ & $\begin{array}{c}\text { Germination speed } \\
\text { index }\end{array}$ \\
\hline 20 & $70.5 \mathrm{a}^{*}$ & $24.0 \mathrm{~b}$ & $29.3 \mathrm{~b}$ \\
25 & $75.0 \mathrm{a}$ & $42.5 \mathrm{a}$ & $38.9 \mathrm{a}$ \\
30 & $50.0 \mathrm{~b}$ & $13.5 \mathrm{c}$ & $18.7 \mathrm{c}$ \\
$20-30$ & $71.5 \mathrm{a}$ & $29.5 \mathrm{~b}$ & $31.1 \mathrm{~b}$ \\
\hline $\mathrm{CV}(\%)$ & 7.3 & 10.4 & 10.8 \\
\hline
\end{tabular}

*Average values followed by same letters in the same column do not differ by the Tukey test $(5 \%)$ (médias seguidas de mesma letra nas colunas não diferem entre si pelo teste de Tukey $(5 \%))$.

Table 2. Dead and dormant seeds (\%), and abnormal daisy seedlings (\%), according to exposure to different temperatures during germination (sementes dormentes e mortas (\%) e plântulas anormais (\%) de margarida sob diferentes temperaturas de germinação). Viçosa, UFV, 2009.

\begin{tabular}{lccc}
\hline $\begin{array}{l}\text { Temperature } \\
\left({ }^{\circ} \mathbf{C}\right)\end{array}$ & Dead seeds (\%) & $\begin{array}{c}\text { Abnormal seedlings } \\
(\%)\end{array}$ & $\begin{array}{c}\text { Dormant seeds } \\
(\%)\end{array}$ \\
\hline 20 & $4.5 \mathrm{~b}^{*}$ & $5.3 \mathrm{c}$ & $19.8 \mathrm{~b}$ \\
25 & $2.5 \mathrm{ab}$ & $7.5 \mathrm{bc}$ & $15.0 \mathrm{~b}$ \\
30 & $6.0 \mathrm{a}$ & $16.0 \mathrm{a}$ & $27.8 \mathrm{a}$ \\
$20-30$ & $3.5 \mathrm{~b}$ & $11.0 \mathrm{~b}$ & $14.0 \mathrm{~b}$ \\
\hline $\mathrm{CV}(\%)$ & 28.9 & 18.0 & 14.0 \\
\hline
\end{tabular}

*Average values followed by same letter in the same column do not differ by the Tukey test (5\%) (médias seguidas de mesma letra nas colunas não diferem entre si pelo teste de Tukey (5\%)). were observed with seeds of black sucupira (B. virgilioides) that presented similar behavior when maintained at the temperature of $30^{\circ} \mathrm{C}$. On this species the phase I of germination is the period corresponding to 12 hours of soaking (Albuquerque et al., 2009). According to Bewley \& Black (1994), since the phase I is a physical process and do not depend on the metabolic activity, it can occur both in viable and dead seeds provided that there is not impediment to the water flow through the tegument.

The duration of phase II was longer, about 48 hours, with reduced weight gain (Figure 1). It is characterized by the less soaking rate and is known as stationary, where the mobilization of the reserves metabolized in the phase I to the embryonic axis occurs. Similarly to what is found in daisy seeds, in soybean seeds, the beginning of the phase II occurs at around 12 hours, but the duration time was shorter, from 12 to 30 hours (Villela et al., 2007). According to Rodrigues et al. (2008), the behavior of the water absorption and the duration of the phases may differ among species, cultivars or lots, due to genetic differences or the physiological quality of the seed lot.

The phase III began after 48 hours, and was evidenced by the radicle protrusion (Figure 1). At this phase, the weight gain was more expressive than in the previous phase because a higher amount of water was necessary to restart the growth of the embryonary axis and formation of the vegetative structures (Pereira et al., 2007; Albuquerque et al., 2009).

In the package of daisy seeds was indicate the germination of $81 \%$. But, after the test the percentage was lower, not depending of the temperatures tested (Table 1), demonstrating that there are divergences between the results issued in the commercial packages of seeds and the real germination detected in laboratory. Therefore, stricter supervision should be adopted in the trade of ornamental plant seeds, as reported by Stefanello et al. (2006).

The temperature of $30^{\circ} \mathrm{C}$ allowed 


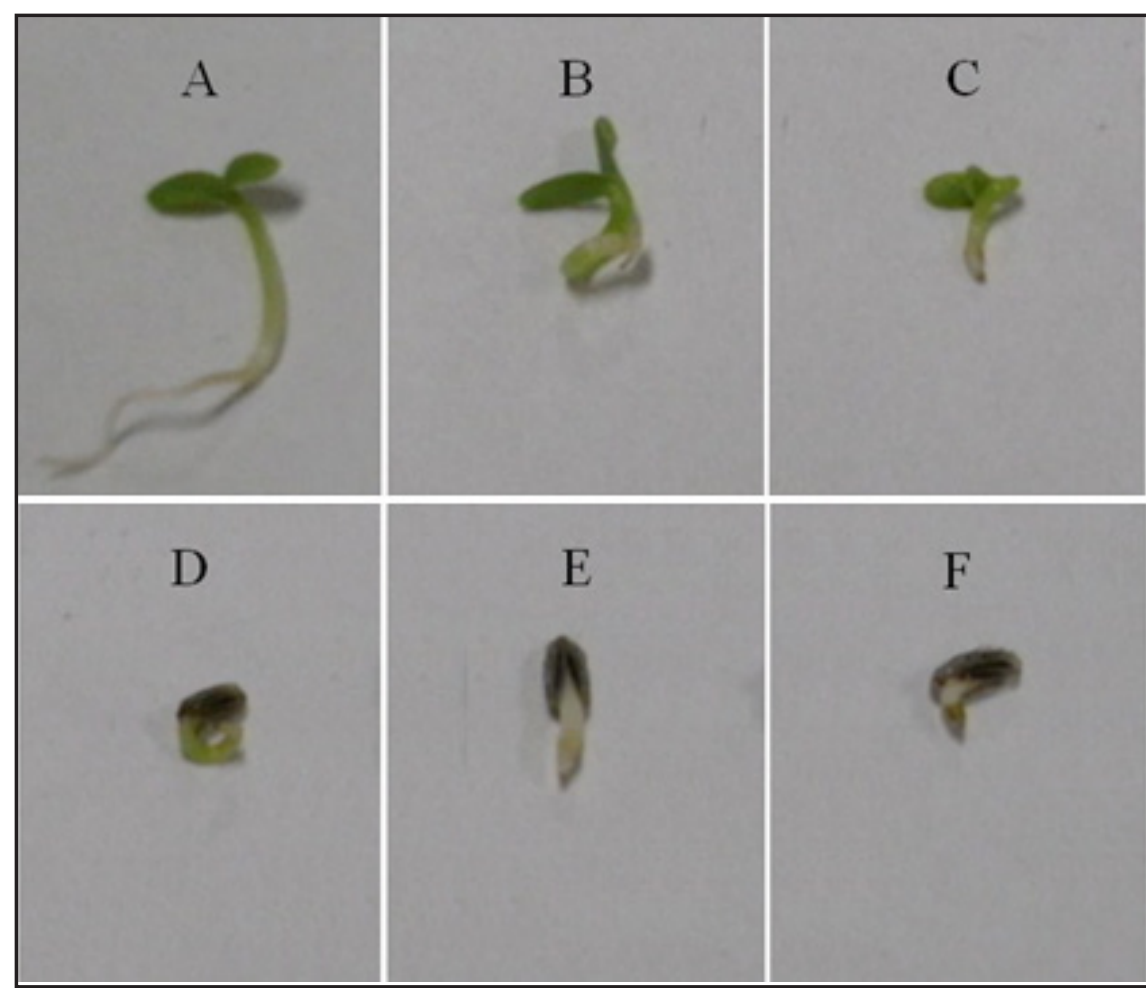

Figure 2. Morphology of daisy seedlings: normal seedlings (A), seedlings with malformed roots $(\mathrm{B}-\mathrm{C})$, seedlings without the formation of the aerial part (D-E) and seedling with roots infected by fungus $(\mathrm{F})$ (caracterização morfológica de plântulas de margarida em fase inicial de desenvolvimento: plântula normal (A), plântula com má formação de raiz (B-C), plântula sem formação de parte aérea (D-E) e plântula com a raiz infectada por fungo (F)). Viçosa, UFV, 2009.

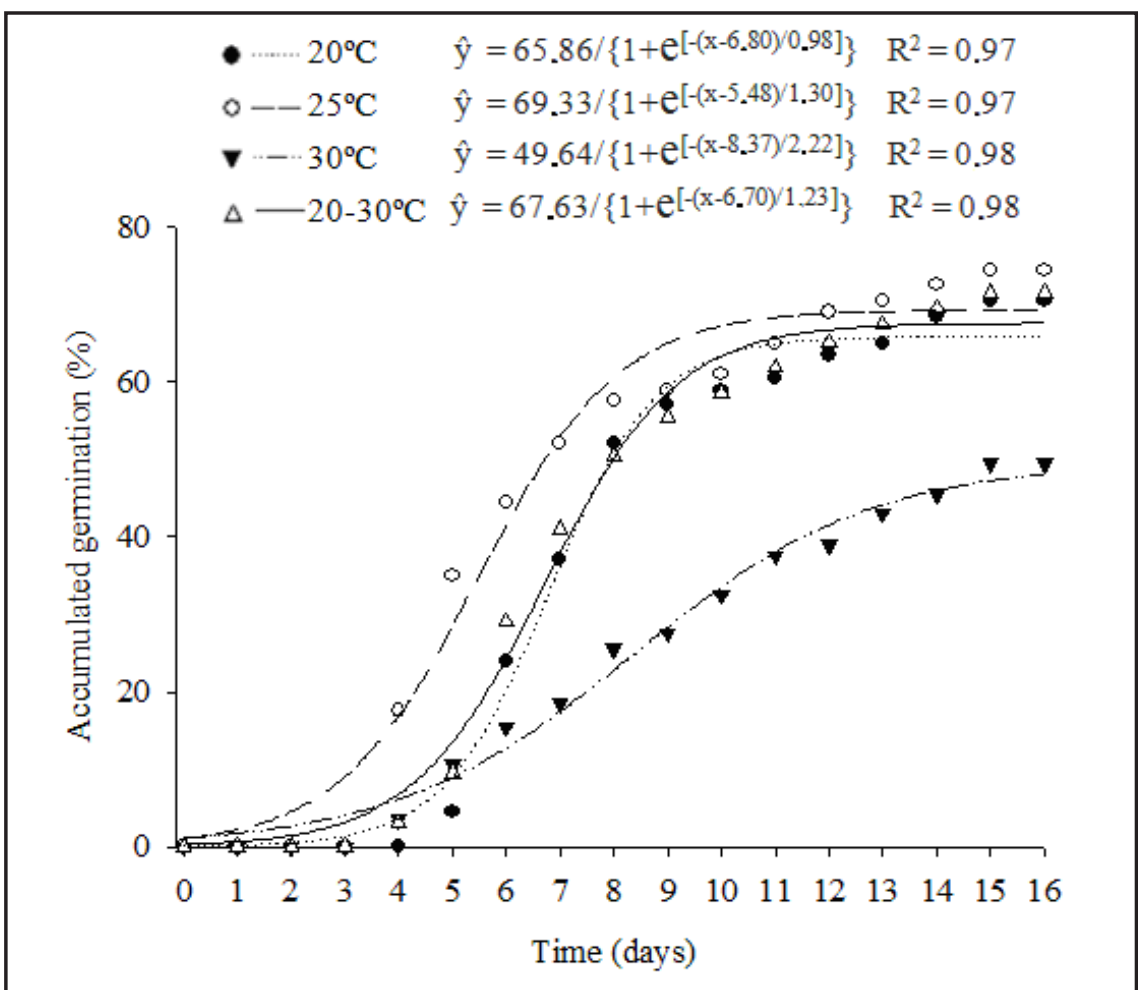

Figure 3. Accumulated germination of daisy seeds exposed to constant temperatures of 20, 25,30 and alternate temperature, between $20-30^{\circ} \mathrm{C}$ (germinação acumulada de sementes de margarida expostas às temperaturas constantes de 20,25, 30 e temperatura alternada de 20-30 $0^{\circ}$ ). Viçosa, UFV, 2009.
$50 \%$ of germination of the seeds, which is lower than the percentages observed under the other temperatures. The Rules for Seed Analysis (RAS) recommend alternate temperatures of $20-30^{\circ} \mathrm{C}$ or constant of $20^{\circ} \mathrm{C}$ for Chrysanthemum indicum, C. nivelli and C. parthenium, while for the species $C$. carinatum, C. coronarium, $C$. segetum and $C$. coccinemum, the conditions of 20$30^{\circ} \mathrm{C}$ or constant of $15^{\circ} \mathrm{C}$ are indicated (Brasil, 2009). Considering that daisy is a species that comes from temperate regions, the temperature of $30^{\circ} \mathrm{C}$ may have caused thermoinhibition to the germination process. This condition stimulated the synthesis of the abscisic acid (ABA) and inhibited the synthesis of gibberellin (GA). Such regulation was considered an adaptive response of these species to abiotic stress, which results in lower percentages of germination (Yoshioka et al., 1998; Toh et al., 2008). Supraoptimal temperatures also decreased the germination percentage of Strelitzia reginae seeds, due to the changes in metabolic processes, therefore the most appropriate temperature for both species was $25^{\circ} \mathrm{C}$ (Barbosa et al., 2005).

The temperatures of $20^{\circ} \mathrm{C}$ and alternate of $20-30^{\circ} \mathrm{C}$ allowed intermediate responses that did not differ (Table 1). in this study we used seeds from the same lot. Thus, the variations caused by the different temperatures lead to infer that the highest physiological potential of daisy seeds is expressed at $25^{\circ} \mathrm{C}$, since this condition allowed the achievement of a higher number of normal seedlings, in comparison to the others.

The germination speed index is much affected by the temperature. Seeds maintained at the temperature of $25^{\circ} \mathrm{C}$ germinated faster than those that germinated at the constant temperature of $20^{\circ} \mathrm{C}$ or alternate of $20-30^{\circ} \mathrm{C}$. The temperature of $30^{\circ} \mathrm{C}$ caused the slowest germination, which can be partially explained by the thermoinhibitory effect mentioned by Toh et al. (2008). The thermoinhibitory effect was observed in seeds of many species under temperatures of $35^{\circ} \mathrm{C}$, mainly affecting the speed of germination (Akman, 2009). 
The lowest number of dead seeds was observed at $25^{\circ} \mathrm{C}$; the highest percentage of dead seeds was achieved at the temperature of $30^{\circ} \mathrm{C}$, indicating that high temperatures cause critic damage to the germination metabolism of the seeds (Table 2). The highest percentage of dormant seeds was observed at the temperature of $30^{\circ} \mathrm{C}$, and it leads to infer that the germination process was thermoinhibited. The highest percentage of abnormal seedlings was also observed at the temperature of $30^{\circ} \mathrm{C}$. This condition presented the highest negative effects on the performance of the seeds.

Similarly to our results, Akman (2009) observed that there were changes in the morphology of radicles and coleoptiles of lettuce seedlings when these were soaked at temperatures higher than the ideal, inhibiting their germination. Possible changes in hormone levels may have inhibited cell elongation, affecting the growth of embryo and leading to the occurrence of the highest percentage of dead seeds and abnormal seedlings characterized by the late emission of the structures essential to the development of the plant, observed at the temperature of $30^{\circ} \mathrm{C}$.

According to the rules for analyze of seeds a normal plant should have all its essential structures present, developed and healthy as can be seen. When this pattern does not occur, the seedlings are classified as abnormal (Brasil, 2009). Seedlings with malformed roots, without the aerial part and with roots infected by fungus were the main abnormal characteristics observed (Figure 2). In this study we characterized seedlings with different abnormalities that can be used as reference in the evaluation of germination tests of this species.

The daisy seeds started radicle protrusion on the fourth day after the beginning of the germination test under all the temperatures tested. However, the stabilization of the germination was influenced by temperature, and it occurred on the days 14, 12, 14 and 15 under temperatures of 20, 25, 20-30 and $30^{\circ} \mathrm{C}$, respectively (Figure 3 ).
The evolution of the germination of seeds maintained at $25^{\circ} \mathrm{C}$ stabilized four days before those maintained at $30^{\circ} \mathrm{C}$; this difference should be considered as determinant in the production of daisy seedlings because the conditions for faster germination of seeds allow the formation of more homogeneous stands and, consequently, seedlings of better quality and more income for producers.

In summary we observed that the seeds presented a triphasic pattern of germination. The duration of the phases I and II is 12 and 48 hours, respectively. The radicle protrusion occurs 60 hours after the beginning of the soaking at $25^{\circ} \mathrm{C}$. The seeds presented thermoinhibition at the temperature of $30^{\circ} \mathrm{C}$. The exposure to this temperature increases the percentage of dead and dormant seeds and cause abnormality to the seedlings. The temperature of $25^{\circ} \mathrm{C}$ is the most appropriate for the germination of the daisy seeds.

\section{REFERENCES}

AKMANZ. 2009. Comparison of high temperature tolerance in maize, rice and sorghum seeds by plant growth regulators. Journal of Animal and Veterinary Advances 8:358-361.

ALBUQUERQUE KS; GUIMARÃES RM; ALMEIDA IF; CLEMENTE ACS. 2009. Alterações bioquímicas durante a embebição de sementes de sucupira-preta (Bowdichia virgilioides Kunth.). Revista Brasileira de Sementes 31: 12-19.

AMATO ALP; MAIA FC; MAIA MS; CAETANO LS; SIMIONI SB; CONTO L; BONINI FILHO RM. 2007. Estabelecimento de condições de luz e temperatura na germinação de sementes de amendoim forrageiro. Revista Brasileira de Sementes 29: 61-66.

BARBOSA JG; ALVARENGA EM; DIAS DCFS; VIEIRA AN. 2005. Efeito da escarificação ácida e de diferentes temperaturas na qualidade fisiológica de sementes de Strelitzia regina. Revista Brasileira de Sementes 27: 71-77.

BEWLEY JD; BLACK M. 1994. Seeds: Physiology of development and germination. New York: Plenum Press. 445p.

BRASIL. 2009. Regras para análise de sementes. Brasília: Ministério da agricultura. Secretaria nacional de defesa agropecuária. 395p.

CEAGESP. Companhia de entreposto e armazéns gerais de São Paulo. 2010, 16 de abril. Cotações. Disponível em: http://www.ceagesp. gov.br/cotacoes

CERATTI M; PAIVAPDO; SOUSA M; TAVARES
TS. 2007. Comercialização de flores e plantas ornamentais no segmento varejista no município de Lavras-MG. Ciência e Agrotecnologia 31: 1212-1218.

GUIMARÃES MA; DIAS DCFS; LOUREIRO ME. 2008. Hidratação de sementes. Revista Trópica 2: 31-39.

KIKUTI ALP; MARCOS FILHO J. 2007. Potencial fisiológico de sementes de couveflor e desenvolvimento das plantas em campo. Revista Brasileira de Sementes 29: 107-113.

LANDGRAF PRC; PAIVA PDO. 2009. Produção de flores cortadas no estado de Minas Gerais. Ciência e Agrotecnologia 33: 120-126.

MAGUIRE JD. 1962. Speed of germination aid in selection and evaluation for emergence and vigor. Crop Science 2: 176-177.

MARCOS FILHO J. 1999. Teste de envelhecimento acelerado. In: KRZYZANOWSKI FC; VIEIRARD; FRANÇA NETO JB (eds). Vigor de sementes: conceitos e testes. Londrina: ABRATES. cap.3., p.1-24.

MITICH LW. 2000. Oxeye daisy (Chrysanthemum leucanthemum L.), the white-flowered gold flower. Weed Technology 14: 659-662.

PEREIRA MD; DIAS DCFS; DIAS LAS; ARAÚJO EF. 2007. Hydration of carrot seeds in relation to osmotic potential of solution and conditioning method. Revista Brasileira de Sementes 29: 126-133.

RODRIGUES APDC; LAURA VA; CHERMOUTH KS; GADUM J. 2008. Absorção de água por semente de salsa, em duas temperaturas. Revista Brasileira de Sementes 30: 49-54.

RODRIGUES APDC; LAURA VA; CHERMOUTH KS; GADUM J. 2009. Osmocondicionamento de sementes de salsa (Petroselinum sativum Hoffm.) em diferentes potenciais hídricos. Ciência e Agrotecnologia 33: 1288-1294.

STEFANELLO R; GARCIA DC; MENEZES NL; WRASSE CF. 2006. Influência da luz, temperatura e estresse hídrico na germinação de sementes de anis. Revista Brasileira de Agrociência 12: 45-50.

TOH S; IMAMURA A; WATANABE A; NAKABAYASHI K; OKAMOTO M; JIKUMARU Y; HANADA A; ASO Y; ISHIYAMA K; TAMURA N; IUCHI S; KOBAYASHI M; YAMAGUCHI S; KAMIYA Y; NAMBARA E; KAWAKAMI N. 2008. High temperature-induced abscisic acid biosynthesis and its role in the inhibition of gibberellin action in Arabidopsis seeds. Plant Physiology 146: 1368-1385.

VILLELA FA; NOVEMBRE ADLC; MARCOS FILHO J. 2007. Estado energético da água na germinação de sementes de soja. Revista Brasileira de Sementes 29: 27-34.

YOSHIOKA T; ENDO T; SATOH S. 1998. Restauration of seed germination at supraoptimal temperatures by fluridone, an inhibitor of abscisic acid biosynthesis. Plant and Cell Physiology 39: 307-312. 